Article

\title{
Serum Klotho in Living Kidney Donors and Kidney Transplant Recipients: A Meta-Analysis
}

\author{
Charat Thongprayoon ${ }^{1, *}$, Javier A. Neyra ${ }^{2,3,4}$, Panupong Hansrivijit ${ }^{5}$, Juan Medaura ${ }^{6}$, \\ Napat Leeaphorn ${ }^{7}$, Paul W. Davis ${ }^{6}$, Wisit Kaewput ${ }^{8}{ }^{(D)}$, Tarun Bathini ${ }^{9}$, Sohail Abdul Salim ${ }^{6}$, \\ Api Chewcharat ${ }^{1}$, Narothama Reddy Aeddula ${ }^{10}$ (D), Saraschandra Vallabhajosyula ${ }^{11}$, \\ Michael A. Mao ${ }^{12}$ and Wisit Cheungpasitporn ${ }^{6, *(D)}$
}

3 Charles and Jane Pak Center for Mineral Metabolism and Clinical Research, Dallas, TX 75390, USA

4 Division of Nephrology, Department of Internal Medicine, University of Texas Southwestern Medical Center, Dallas, TX 75390, USA

5 Department of Internal Medicine, University of Pittsburgh Medical Center Pinnacle, Harrisburg, PA 17105, USA; hansrivijitp@upmc.edu

6 Division of Nephrology, Department of Medicine, University of Mississippi Medical Center, Jackson, MS 39216, USA; jmedaura@umc.edu (J.M.); pwdavis@umc.edu (P.W.D.); sohail3553@gmail.com (S.A.S.)

7 Renal Transplant Program, University of Missouri-Kansas City School of Medicine/Saint Luke's Health System, Kansas City, MO 64110, USA; napat.leeaphorn@gmail.com

8 Department of Military and Community Medicine, Phramongkutklao College of Medicine, Bangkok 10400, Thailand; wisitnephro@gmail.com

9 Department of Internal Medicine, University of Arizona, Tucson, AZ 85721, USA; tarunjacobb@gmail.com

10 Division of Nephrology, Department of Medicine, Deaconess Health System, Evansville, IN 47710, USA; dr.anreddy@gmail.com

11 Department of Cardiovascular Medicine, Mayo Clinic, Rochester, MN 55905, USA; Vallabhajosyula.Saraschandra@mayo.edu

12 Division of Nephrology and Hypertension, Mayo Clinic, Jacksonville, FL 32224, USA; mao.michael@mayo.edu * Correspondence: charat.thongprayoon@gmail.com (C.T.); wcheungpasitporn@gmail.com (W.C.)

Received: 21 May 2020; Accepted: 9 June 2020; Published: 12 June 2020

check for updates 
living kidney donors had lower serum klotho levels with a MD of $=-92.41 \mathrm{pg} / \mathrm{mL}$ (two studies; $95 \%$ CI -180.53 to $-4.29 \mathrm{pg} / \mathrm{mL}$ ). There is a significant reduction in serum klotho levels after living kidney donation and an increase in serum klotho levels after KTx. Future prospective studies are needed to assess the impact of changes in klotho on clinical outcomes in KTx recipients and living kidney donors.

Keywords: klotho; $\alpha$-Klotho; FGF-23; kidney transplantation; kidney donor; renal transplantation; transplantation; Nephrology; CKD-MBD; CKD-Mineral and Bone Disorder

\section{Introduction}

$\alpha$-Klotho (klotho) is a membrane protein that is highly expressed in the kidney, especially in the distal tubular epithelial cells [1-10]. Membrane-bound klotho regulates phosphate homeostasis by acting as a co-factor of fibroblast growth factor 23 (FGF23) [11-14]. FGF23-Klotho signaling promotes urinary phosphate excretion and suppresses the expression of renal $1 \alpha$-hydroxylase, resulting in reduced vitamin D-dependent intestinal absorption of calcium and phosphate [11,15]. Altogether, FGF23-Klotho signaling regulates phosphate metabolism and prevents phosphate retention [16-20]. Soluble klotho can be detected in the circulation in two forms: (1) cleaved klotho, which is derived from cleavage of the extracellular domain of membrane klotho, and potentially (2) secreted klotho, which is derived from an alternatively spliced klotho mRNA transcript [21,22].

Soluble klotho displays diverse physiological effects and hormonal functions, including the reduction of oxidative stress and the inhibition of intracellular insulin and insulin-like growth factor 1 (IGF-1) signaling [15,23-28]. Klotho protects the kidney by suppression of apoptosis [29,30] and cell senescence [31,32], suppression of fibrosis [33-37], and upregulation of autophagy [3,38] in renal tubular cells. Klotho-deficient mice develop premature aging, hyperphosphatemia, vascular calcification and endothelial dysfunction, and have shorter lifespans, while klotho overexpressing mice have $20-30 \%$ longer lifespans than wild type mice $[2,24,39]$. Since klotho expression is the most abundant in the kidney [40], patients with kidney diseases, including acute kidney injury (AKI) and chronic kidney disease (CKD), are found to have a significant reduction in klotho expression and soluble levels [41-51]. Studies have demonstrated that serum klotho declines in progressive human CKD with the lowest serum klotho levels among patients with end-stage kidney disease (ESKD) on dialysis [41,48]. Low serum klotho is associated with increased mortality and cardiovascular events among patients with ESKD [52].

When compared to treatment with chronic dialysis, kidney transplantation (KTx) is the best therapeutic option for patients with ESKD and is associated with increased survival and better quality of life [53-56]. In addition, living donor KTx provides greater allograft longevity than those transplanted from a deceased donor [57]. However, changes in serum klotho levels and the impact of klotho on outcomes among KTx recipients and kidney donors remain unclear [58-75]. Thus, we conducted this systematic review and meta-analysis to assess serum klotho levels and the impact of klotho on outcomes among KTx recipients and kidney donors.

\section{Methods}

\subsection{Search Strategy and Literature Review}

A systematic literature search of MEDLINE (1946 to October 2019), EMBASE (1988 to October 2019), and the Cochrane Database of Systematic Reviews (database inception to October 2019) was conducted (1) to assess studies evaluating serum klotho levels and effects of klotho on outcomes among KTx recipients and kidney donors. The systematic literature review was undertaken independently by two investigators (C.T. and W.C.) using a search strategy that combined the terms of ("klotho" OR 
"klotho protein" OR "klotho gene") AND ("kidney transplantation" OR "renal transplantation" OR "kidney donor") which is provided in online Supplementary Materials (Table S1). No language limitation was applied. A manual search for conceivably relevant studies using references of the included articles was also performed. This study was conducted by the PRISMA (Preferred Reporting Items for Systematic Reviews and Meta-Analysis) statement [76]. The data for this meta-analysis are publicly available through the Open Science Framework (URL: https://osf.io/kx9we/).

\subsection{Selection Criteria}

Eligible studies must have been (1) clinical trials or observational studies (cohort, case-control, or cross-sectional studies) that evaluated serum klotho levels and effects of klotho on outcomes among KTx recipients or kidney donors, and (2) studies that presented data to calculate mean differences (MDs) with $95 \%$ confidence intervals (CIs) that evaluated changes in serum klotho before and after KTx/kidney donation or compared serum klotho between KTx patients/donors and a control group composed of non-KTx or non-donor controls. Retrieved articles were individually reviewed for eligibility by the two investigators (C.T. and W.C.). Discrepancies were addressed and solved by joint consensus. Inclusion was not limited by the size of the study.

\subsection{Data Abstraction}

A structured data collecting form was used to obtain the following information from each study including the title, name of the first author, publication year, year of the study, country where the study was conducted, demographic data of kidney transplant recipients and donors, methods used to measure serum klotho, serum klotho levels, estimated glomerular filtration rate (eGFR), control group, and adjusted effect estimates with $95 \% \mathrm{CI}$ and covariates that were adjusted for in the multivariable analysis. This data extraction process was independently performed by two investigators (C.T. and W.C.).

\subsection{Statistical Analysis}

Analyses were performed utilizing the Comprehensive Meta-Analysis 3.3 software (version 3; Biostat Inc., Englewood, NJ, USA). Adjusted point estimates from each study were consolidated by the generic inverse variance approach of DerSimonian and Laird, which designated the weight of each study based on its variance [77]. The summary statistics for each outcome were the mean change from baseline and standard deviation (SD) of the mean change. The mean change in each group was obtained by subtracting the final mean from the baseline mean. The MDs were preferred since all studies use the same continuous outcome and unit of measure $(\mathrm{pg} / \mathrm{mL})$ of serum klotho and FGF-23 levels. The SD of mean change was computed, assuming a conservative correlation coefficient of 0.5 [78]. Effects sizes of 0.2 were interpreted as small, those of 0.5 as moderate, and of 0.8 as large [79]. Given the possibility of between-study variance, we used a random-effect model rather than a fixed-effect model. Cochran's $Q$ test and $\mathrm{I}^{2}$ statistics were applied to determine between-study heterogeneity. A value of $\mathrm{I}^{2}$ of $0 \%$ to $25 \%$ represents insignificant heterogeneity, $26 \%$ to $50 \%$ low heterogeneity, $51 \%$ to $75 \%$ moderate heterogeneity and $76-100 \%$ high heterogeneity [80]. The presence of publication bias was assessed by the Egger test [81].

\section{Results}

A total of 132 potentially eligible articles were identified using our search strategy. After the exclusion of 93 articles based on title and abstract for clearly not fulfilling inclusion criteria on the basis of the type of article, study design, population or outcome of interest, or due to being duplicates, 39 articles were left for full-length review. Eighteen of these were excluded from the full-length review as they did not report the outcome of interest, while six articles were excluded because they were not observational studies. Thus, 15 studies (10 cohort studies [58-67] with a total of $431 \mathrm{KTx}$ recipients and 5 cohort studies [68-72] with a total of 108 living kidney donors) were included. The literature retrieval, review, and selection process are demonstrated in Figure 1. 


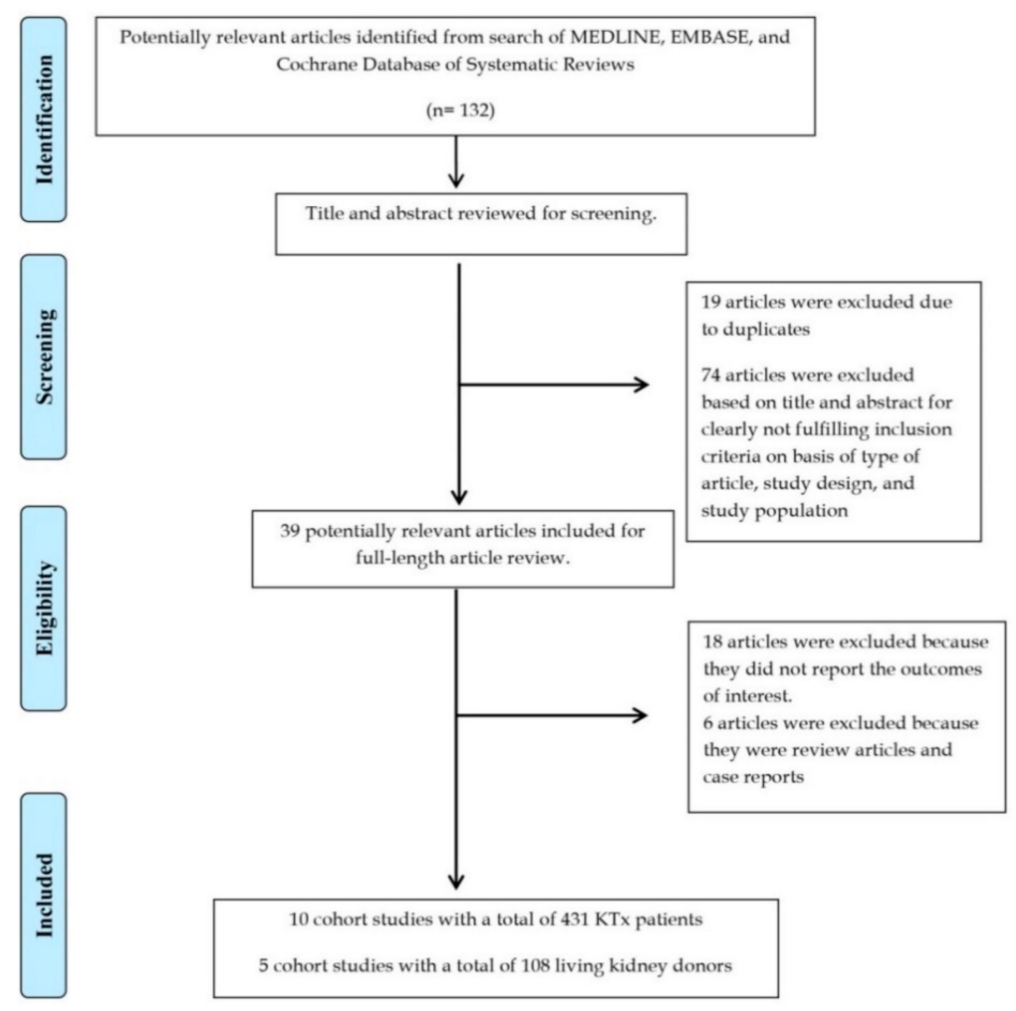

Figure 1. Outline of our search methodology. Abbreviation: KTx, kidney transplant.

\subsection{Serum Klotho after Kidney Transplantation}

The characteristics of the included studies assessing serum klotho after kidney transplantation are presented in Tables 1 and 2. After KTx, there was a significant increase in serum klotho levels in recipients (at 4 to 13 months post-KTx) in reference to baseline levels before KTx with a mean difference (MD) of $243.11 \mathrm{pg} / \mathrm{mL}$ (three studies; 95\% CI 67.41 to $418.81 \mathrm{pg} / \mathrm{mL}, \mathrm{I}^{2}=93 \%$ ), Figure $2 \mathrm{~A}$. There were significant reductions in serum PTH and phosphate levels with MDs of $-134.65 \mathrm{pg} / \mathrm{mL}$ (95\% CI -176.09 to $-93.21 \mathrm{pg} / \mathrm{mL}, \mathrm{I}^{2}=0 \%$ ) and $-2.81 \mathrm{mg} / \mathrm{dL}\left(95 \% \mathrm{CI}-3.46\right.$ to $-2.16 \mathrm{mg} / \mathrm{dL}, \mathrm{I}^{2}=97 \%$ ), respectively. There was no significant change in serum calcium levels with a MD of $0.37 \mathrm{mg} / \mathrm{dL}$ ( $95 \% \mathrm{CI},-0.05$ to $\left.0.79 \mathrm{mg} / \mathrm{dL}, \mathrm{I}^{2}=83 \%\right)$. Although $\mathrm{KTx}$ recipients had lower serum klotho levels with a $\mathrm{MD}$ of $=-234.50 \mathrm{pg} / \mathrm{mL}$ (five studies; $95 \% \mathrm{CI}-444.84$ to $-24.16 \mathrm{pg} / \mathrm{mL}, \mathrm{I}^{2}=93 \%$, Figure $2 \mathrm{~B}$ ) compared to healthy unmatched volunteers, one study demonstrated comparable klotho level between KTx recipients and eGFR-matched controls [66]. Two studies demonstrated high serum klotho levels in deceased donors as a prognostic marker for good allograft function within one year after KTx $(p<0.05)[59,60]$. 
Table 1. Characteristics of the included studies assessing serum klotho after kidney transplantation.

\begin{tabular}{|c|c|c|c|c|c|c|c|c|}
\hline Study & Year & Country & N-KTx & Characteristics-KTx & Klotho before KTx (pg/mL) & Other Markers before KTx & Kloth after KTx (pg/mL) & Other Markers after KTx \\
\hline Kubota et al. & & Japan & 20 & $\begin{array}{l}\text { Age } 6.9 \pm 4.5 \text { years } \\
\text { Male } 12(60 \%)\end{array}$ & $988 \pm 122$ & $\begin{array}{c}\text { FGF23 } \\
5343 \pm 1350 \mathrm{pg} / \mathrm{mL}\end{array}$ & $\begin{array}{l}\text { At } 4 \text { months } \\
1405 \pm 125\end{array}$ & N/A \\
\hline Tan et al. & 2017 & Australia & 29 & $\begin{array}{l}\text { Age } 49 \text { (35-55) years } \\
\text { Male } 17(59 \%)\end{array}$ & $307(279-460)$ & $\begin{array}{c}\text { iFGF23 } \\
2060(825-5075) \mathrm{pg} / \mathrm{mL} \\
\text { eGFR } \\
7.4(6.5-8.7) \mathrm{mL} / \mathrm{min} / 1.73 \mathrm{~m}^{2}\end{array}$ & 460 (311-525) & $\begin{array}{c}\text { At } 52 \text { weeks } \\
\text { iFGF23 } \\
64(34-88) \mathrm{pg} / \mathrm{mL} \\
\text { eGFR } \\
60.4(50.5-71.6) \mathrm{mL} / \mathrm{min} / 1.73 \mathrm{~m}^{2}\end{array}$ \\
\hline Mizusaki et al. & 2019 & Japan & 36 & Age $38.1 \pm 14$ years & 211.8 & eGFR & At 1 year & $\begin{array}{c}\text { At } 1 \text { year } \\
\text { eGFR }\end{array}$ \\
\hline
\end{tabular}

Abbreviations: eGFR, estimated glomerular filtration rate; iFGF23, intact fibroblast growth factor-23; KTx, kidney transplant; N/A, not available.

Table 2. Characteristics of the included studies comparing serum klotho between KTx recipients and healthy volunteers.

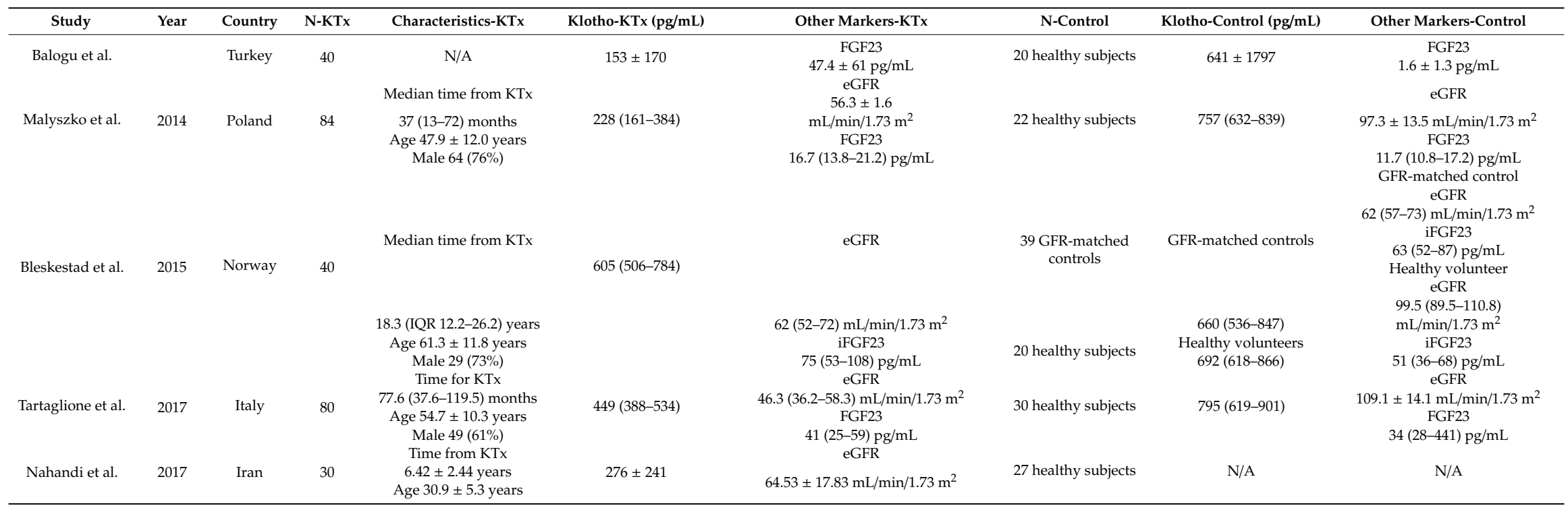

Abbreviations: eGFR, estimated glomerular filtration rate; FGF23, fibroblast growth factor-23; KTx, kidney transplant; N/A, not available. 


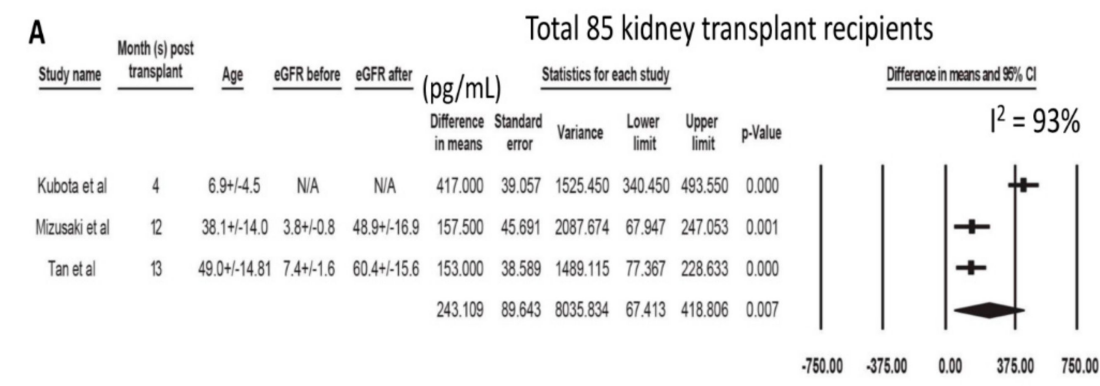

Lower Serum Klotho Higher Serum Klotho

B

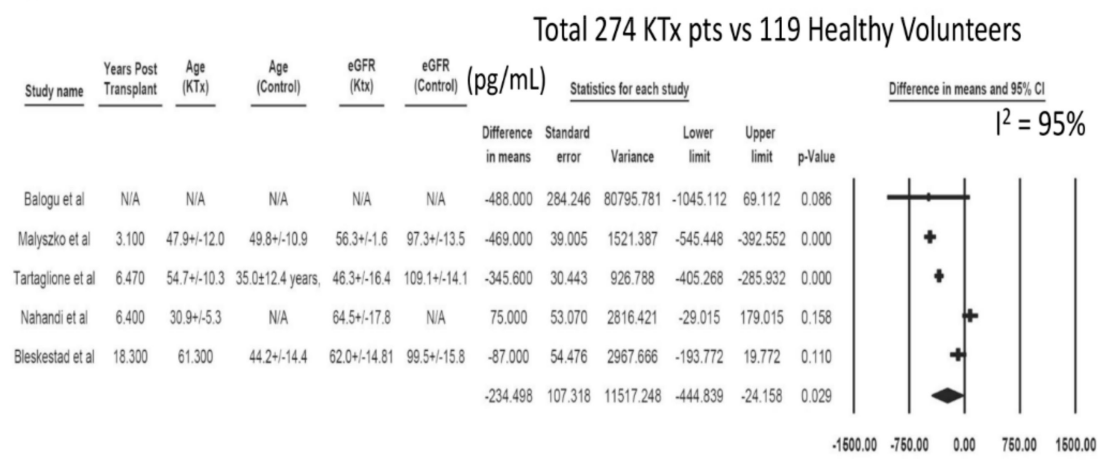

Favours Healthy Control Favors Kidney Transplant

Figure 2. (A) Change in Serum Klotho in KTx Recipients after Kidney Transplant. (B) Serum Klotho in KTx Recipients Compared to Unmatched Healthy Volunteers.

\subsection{Serum Klotho after Living Kidney Donation}

The characteristics of the included studies assessing serum klotho after kidney transplantation are presented in Tables 3 and 4. A total of 108 living kidney donors were identified from five cohort studies. After kidney donation, there was a significant decrease in serum klotho levels post-nephrectomy (day 3 to day 5) with a mean difference (MD) of $-232.24 \mathrm{pg} / \mathrm{mL}$ (three studies; $95 \% \mathrm{CI}-299.41$ to $-165.07 \mathrm{pg} / \mathrm{mL}, \mathrm{I}^{2}=0$ ), Figure $3 \mathrm{~A}$. At one year following the kidney donation, serum klotho levels remained lower than baseline before nephrectomy with a MD of $=-110.80 \mathrm{pg} / \mathrm{mL}$ (two studies; $95 \%$ CI -166.35 to $\left.-55.24 \mathrm{pg} / \mathrm{mL}, \mathrm{I}^{2}=5\right)$, Figure 3B.

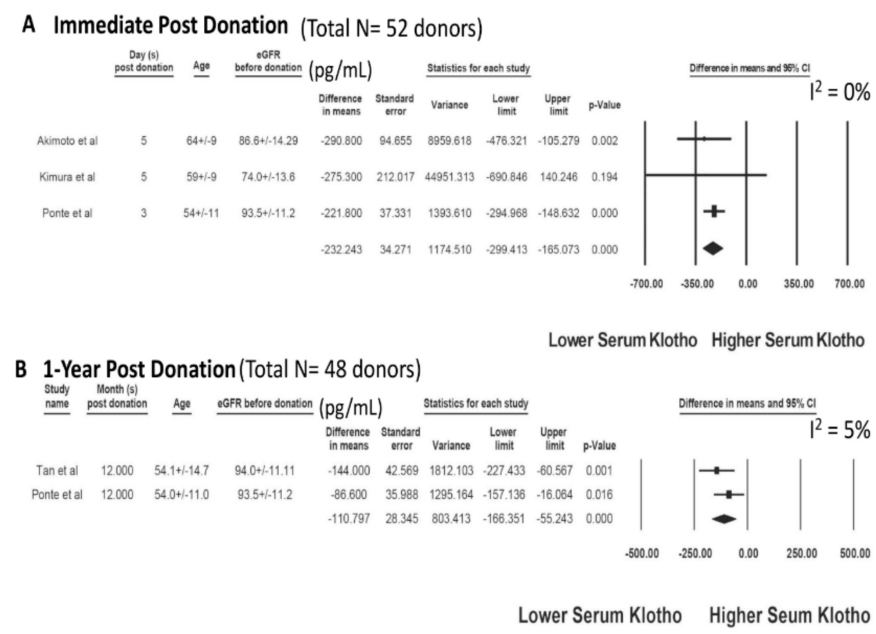

Figure 3. Changes in serum klotho after living kidney donation: (A) immediate post-donation and (B) one year post-donation. 
Table 3. Characteristics of the included studies evaluating serum klotho after living kidney donation.

\begin{tabular}{|c|c|c|c|c|c|c|c|c|}
\hline Study & Year & Country & N-Donor & Characteristics-Donor & $\begin{array}{l}\text { Klotho before Donor } \\
\text { Nephrectomy (pg/mL) }\end{array}$ & $\begin{array}{l}\text { Other Markers before } \\
\text { Donor Nephrectomy }\end{array}$ & $\begin{array}{l}\text { Klotho after Donor } \\
\text { Nephrectomy (pg/mL) }\end{array}$ & $\begin{array}{l}\text { Other Markers after } \\
\text { Donor Nephrectomy }\end{array}$ \\
\hline \multirow[b]{2}{*}{ Akimoto et al. } & \multirow[b]{2}{*}{2013} & \multirow[b]{2}{*}{ Japan } & \multirow[b]{2}{*}{10} & Age $64 \pm 9$ years & \multirow[b]{2}{*}{$910(755-1132)$} & eGFR & At day 5 & \multirow[b]{2}{*}{$\mathrm{N} / \mathrm{A}$} \\
\hline & & & & $\begin{array}{l}\text { Male } 4(40 \%) \\
\text { Living donor }\end{array}$ & & $87(72-92) \mathrm{mL} / \mathrm{min} / 1.73 \mathrm{~m}^{2}$ & 619 (544.6-688.5) & \\
\hline \multirow[t]{3}{*}{ Ponte et al. } & \multirow[t]{3}{*}{2014} & \multirow[t]{3}{*}{ Switzerland } & \multirow[t]{3}{*}{27} & Age $54 \pm 11$ years & \multirow[t]{3}{*}{$526(482-615)$} & eGFR & At day 3 & $\begin{array}{c}\text { At day } 3 \\
\text { FGF23 } \\
26.9(22.1-38.0) \mathrm{pg} / \mathrm{mL} \\
\text { At day } 360 \\
\text { eGFR }\end{array}$ \\
\hline & & & & Male $15(57 \%)$ & & $\underset{\text { FGF23 }}{95 \pm 11 \mathrm{~mL} / \mathrm{min} / 1.73 \mathrm{~m}^{2}}$ & $\begin{array}{l}304(266-491) \\
\text { At day } 360\end{array}$ & $\begin{array}{c}63 \pm 13 \mathrm{~mL} / \mathrm{min} / 1.73 \mathrm{~m}^{2} \\
\text { FGF23 }\end{array}$ \\
\hline & & & & $\begin{array}{l}\text { Living donor } \\
\text { Age } 59 \pm 9 \text { years }\end{array}$ & & $\begin{array}{c}48.1(37.4-60.0) \mathrm{pg} / \mathrm{mL} \\
\text { eGFR }\end{array}$ & $\begin{array}{l}440(398-613) \\
\text { At day } 5\end{array}$ & $45.2(37.7-56.4) \mathrm{pg} / \mathrm{mL}$ \\
\hline Kimura et al. & 2015 & Japan & 15 & $\begin{array}{l}\text { Male } 8(53 \%) \\
\text { Living donor }\end{array}$ & 1084 (795-1638) & $74 \pm 14 \mathrm{~mL} / \mathrm{min} / 1.73 \mathrm{~m}^{2}$ & $809(638-1357)$ & $\mathrm{N} / \mathrm{A}$ \\
\hline \multirow{2}{*}{ Tan et al. } & \multirow{2}{*}{2017} & \multirow{2}{*}{ Australia } & \multirow{2}{*}{21} & Age $54.1 \pm 14.7$ & \multirow{2}{*}{$564(468-663)$} & $\begin{array}{c}\text { eGFR } \\
94(82-97) \mathrm{mL} / \mathrm{min} / 173 \mathrm{~m}^{2}\end{array}$ & At 12 months & $\begin{array}{l}\text { At } 12 \text { months } \\
\text { eGFR }\end{array}$ \\
\hline & & & & $\begin{array}{l}\text { Male } 13(62 \%) \\
\text { Living donor }\end{array}$ & & $\begin{array}{c}\text { iFGF23 } \\
52 \pm 15 \mathrm{pg} / \mathrm{mL}\end{array}$ & $420(378-555)$ & $\begin{array}{c}\text { iFGF23 } \\
72 \pm 22 \mathrm{pg} / \mathrm{mL}\end{array}$ \\
\hline
\end{tabular}

Abbreviations: eGFR, estimated glomerular filtration rate; FGF23, fibroblast growth factor-23; N/A, not available.

Table 4. Characteristics of the included studies comparing serum klotho between living kidney donors and healthy volunteers.

\begin{tabular}{|c|c|c|c|c|c|c|c|c|c|}
\hline Study & Year & Country & N-Donor & Characteristics-Donor & Klotho-Donor (pg/mL) & Other Markers-Donor & $\mathrm{N}$-Control & Klotho-Control (pg/mL) & Other Markers-Control \\
\hline \multirow{5}{*}{ Thorsen et al. } & \multirow{5}{*}{2016} & \multirow{5}{*}{ Norway } & \multirow{5}{*}{35} & Age $56.5 \pm 9.4$ years & \multirow{5}{*}{$669(409-1161)$} & FGF23 & \multirow{5}{*}{35 healthy subjects } & \multirow{5}{*}{$725(458-1222)$} & FGF23 \\
\hline & & & & Male $21(60 \%)$ & & & & & \\
\hline & & & & Living donor & & $62.6(6.6-112) \mathrm{pg} / \mathrm{mL}$ & & & $51.8(25.9-90) \mathrm{pg} / \mathrm{mL}$ \\
\hline & & & & $\begin{array}{l}\text { Time from donor } \\
\text { nephrectomy }\end{array}$ & & eGFR & & & eGFR \\
\hline & & & & Median 15 years & & $75.8 \pm 12.3 \mathrm{~mL} / \mathrm{min} / 1.73 \mathrm{~m}^{2}$ & & & $99.0 \pm 13.1 \mathrm{~mL} / \mathrm{min} / 1.73 \mathrm{~m}^{2}$ \\
\hline \multirow{4}{*}{ Tan et al. } & \multirow{4}{*}{2017} & \multirow{4}{*}{ Australia } & \multirow{4}{*}{21} & Age $54.1 \pm 14.7$ years & \multirow{4}{*}{$420(378-555)$} & eGFR & \multirow{4}{*}{20 healthy subjects } & \multirow{4}{*}{$517(434-667)$} & eGFR \\
\hline & & & & Male $13(62 \%)$ & & $61(49-69) \mathrm{mL} / \mathrm{min} / 1.73 \mathrm{~m}^{2}$ & & & $97(89-102) \mathrm{mL} / \mathrm{min} / 1.73 \mathrm{~m}^{2}$ \\
\hline & & & & Living donor & & iFGF23 & & & iFGF \\
\hline & & & & $\begin{array}{l}\text { Time from donor } \\
\text { nephrectomy } 1 \text { year }\end{array}$ & & $72 \pm 22 \mathrm{pg} / \mathrm{mL}$ & & & $52 \pm 15 \mathrm{pg} / \mathrm{mL}$ \\
\hline
\end{tabular}


There was no significant change in serum FGF-23 at one year post-donation with a $\mathrm{MD}$ of $=8.19 \mathrm{pg} / \mathrm{mL}$ (two studies; $95 \% \mathrm{CI}-14.24$ to $30.62 \mathrm{pg} / \mathrm{mL}, \mathrm{I}^{2}=85 \%$ ), Figure $4 \mathrm{~A}$. Compared to unmatched healthy volunteers, living kidney donors had lower serum klotho levels with a $\mathrm{MD}$ of $=-92.41 \mathrm{pg} / \mathrm{mL}$ (two studies; $95 \% \mathrm{CI}-180.53$ to $-4.29 \mathrm{pg} / \mathrm{mL}, \mathrm{I}^{2}=44 \%$ ), Figure $4 \mathrm{~B}$.

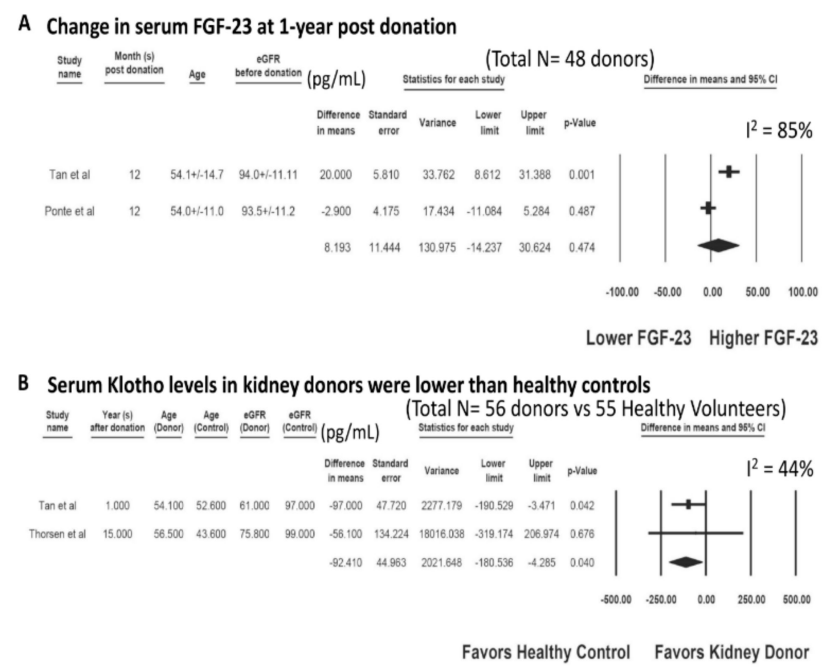

Figure 4. (A) Changes in Serum FGF-23 at one year post-donation and (B) Serum klotho levels in kidney donors compared to unmatched healthy controls.

\subsection{Evaluation for Publication Bias}

A funnel plot was not drawn because of the limited number of studies in each analysis. Generally, tests for funnel plot asymmetry should be used only when there are at least ten study groups, because the power of the test is too low to distinguish chance from real asymmetry [82]. Egger's regression test demonstrated no significant publication bias in all analyses $(p>0.05)$.

\section{Discussion}

In this meta-analysis, we demonstrated that serum klotho levels were significantly increased after successful KTx. While KTx recipients had lower serum klotho levels compared to unmatched healthy volunteers, serum klotho levels in kidney transplant recipients were comparable to those in eGFR-matched controls. Among kidney donors, we found a significant decrease in serum klotho levels post-nephrectomy at day 3 to day 5, which remained lower than baseline before nephrectomy at one year following kidney donation. Compared to healthy volunteers, living kidney donors had lower serum klotho levels.

The findings from our meta-analysis support that klotho is primarily synthesized in the kidneys [40], and transplanting a new kidney into ESKD patients would result in an increase in renal klotho and serum klotho levels post-KTx. In addition to the oligo-anuric state, patients with advanced CKD/ESKD have a significant reduction in klotho and progressively lose the ability to prevent phosphate retention, resulting in hyperphosphatemia, vascular calcification, and cardiovascular disease [83,84]. After successful KTx, in addition to improvement in eGFR, there is also a significant increase in klotho, altogether leading to an improvement in phosphate homeostasis. Recent studies have demonstrated that post-transplant hypophosphatemia after KTx is associated with good kidney allograft function $[85,86]$. Although the actual underlying mechanisms remain unclear, this is likely because excellent quality transplanted kidneys have higher eGFR and klotho expression, resulting in a reduction in phosphate levels post-KTx.

We identified two cohorts of KTx patients who received their kidneys from deceased donors; higher serum klotho levels in these donors were prognostic for good allograft function at one year after KTx $[59,60]$. In the ischemia-reperfusion injury (IRI), which is unavoidable to a certain degree 
in all KTx surgeries, soluble klotho protects renal tubular cells from oxidative damage by inhibiting the insulin/IGF-1 signaling pathway and by inhibition of TGF- $\beta 1$ for decreasing renal fibrosis $[87,88]$, and upregulation of autophagy in renal tubular cells [3,89]. In addition, klotho is also involved in the inhibition of Wnt pathway-associated $\beta$-catenin activation, thus improving renal fibrosis [87]. Compared to patients with early graft function, a lower level of klotho is observed in implantation biopsies among patients with delayed graft function (DGF) [90]. Although data on the effects of klotho on long-term allograft outcomes are limited, it is well known that poor allograft function at one year after KTx and DGF is associated with renal allograft loss [91,92]. Following successful KTx, patients regain functions of klotho via FGF23-Klotho signaling, and with the previously accumulated FGF23, residual hyperparathyroidism, and the use of calcineurin inhibitors (especially cyclosporine) [93-95], post-KTx hypophosphatemia can commonly occur up to $86 \%[85,96,97]$. Post-KTx hypophosphatemia is known to be associated with lower risks of death-censored graft failure and cardiovascular mortality [85]. The association between post-KTx hypophosphatemia and reduced cardiovascular mortality among KTx recipients could be related to the reduction of calcium phosphate product, an important factor associated with vascular calcification and cardiovascular events $[98,99]$. Our study demonstrated that successful KTx can result in a significant increase in serum klotho levels among KTx recipients [85]. In addition, previous literature has demonstrated trending towards normal FGF-23 levels after successful KTx $[42,100]$. Thus, regaining function in FGF23-Klotho signaling after KTx helps promote urinary phosphate excretion and reduced vitamin D-dependent intestinal absorption of calcium and phosphate [11,15], which might explain the association between post-KTx hypophosphatemia and reduced cardiovascular mortality. Future studies are needed to assess the impact of klotho levels on long-term cardiovascular health in KTx recipients, allograft, and patient survival.

Living donors supply approximately $40 \%$ of kidney allografts in the United States [101]. Overall, living kidney donation is considered safe and does not appear to increase long-term mortality compared with controls [102-107]. A recent systematic review of 52 studies comprising 118,426 living kidney donors reassured the safety of living kidney donations with the finding of no difference in all-cause mortality among donors and controls [108]. In addition, a large retrospective population-based matched cohort study of 2028 kidney donors in comparison with 20,280 matched non-donor controls (followed for a median of 6.5 years) demonstrated no difference in the rate of cardiovascular events between the two groups [109]. Although the findings of our study showed a significant reduction in serum klotho at post-operative day 3 to 5 and at one year following kidney donation, the degree of klotho reduction seemed to be attenuated at one year post-donation compared to the early post-operative period. In addition, we found no significant change in serum FGF-23 at one year post-donation. It is possible that after living kidney donation serum klotho is not severely reduced enough to stimulate the rise in serum FGF-23, which occurred in patients with advanced CKD [41,110]. Elevated FGF-23 levels have been shown to be associated with increased mortality and cardiovascular events [111-113]. Thus, no significant increase in FGF-23 levels after living kidney donation is consistent with the findings of no difference in all-cause mortality among donors and controls in previous literature $[108,109]$.

Despite these published reassuring findings of donor safety $[108,109]$, a recent small multicenter study of living kidney donors and healthy controls $(n=124)$ demonstrated an association between living kidney donation and a significant increase in left ventricular mass and reduced aortic distensibility [114]. In addition to functions of klotho via FGF23-Klotho signaling, soluble klotho also has FGF23-independent effects, including endothelial protection from senescence, anti-fibrotic properties, cardioprotection, and prevention of vascular calcifications $[84,115,116]$. Klotho-deficient CKD mice have significant left ventricular hypertrophy $(\mathrm{LVH})$ and cardiac fibrosis compared with wild-type mice [117]. Soluble klotho also provides cardioprotection against stress-induced exaggerated cardiac remodeling through downregulation of transient receptor potential cation channel 6 (TRPC6) [118]. Although an increased LVH and reduced aortic distensibility in living kidney donors could be related to an increased risk of hypertension post living kidney donation [102,103], future studies are required 
to assess whether a reduction in serum klotho levels after living kidney donation may play a role in the higher risk of $\mathrm{LVH}$, and reduced aortic distensibility observed among living kidney donors.

Our meta-analysis is subject to certain limitations. First, although there were comparative groups, all studies are observational, making them susceptible to selection bias. Second, many variables may influence klotho levels in the post-transplant period that may contribute to the heterogeneity between the included studies evaluating changes in serum klotho levels among KTx recipients. Data on medications that may affect endogenous klotho expression in the kidney and soluble levels such as angiotensin II inhibitors and hydroxymethylglutaryl-CoA (HMG-CoA) reductase inhibitors $[17,21,119,120]$ as well as data on immunosuppression were limited in included studies. Lifestyle, diet, psychological stress, and activities such as exercises may also affect serum klotho levels [121-124]. Thus, future prospective studies are needed to assess the impact of changes in klotho on clinical outcomes in KTx recipients and living kidney donors. Third, the follow-up duration of included studies was limited to only one year, and future studies are required to evaluate the impacts of serum klotho levels on long-term clinical outcomes. Fourth, serum klotho is also affected by the aging process and declines with older age [125]. However, we demonstrated an increase in serum klotho levels after KTx at one year and a decrease in klotho levels at immediate postoperative (which is less likely to be affected by the aging process). Lastly, all included studies measured serum klotho levels by ELISA. Recently, immunoprecipitation-immunoblot (IP-IB) assay is shown to be superior to the ELISA and highly correlated with eGFR [126]. However, this technique requires the labor-intensive nature of the IP-IB assay, and further research is needed to evaluate the use of the IP-IB assay in KTx patients.

In conclusion, compared to patients' baseline, serum klotho levels increase early after successful KTx and decrease after living kidney donation, respectively. Future studies are required to assess the impact of serum klotho levels on risk-stratification and patient-centered outcomes in both living donors and KTx recipients.

Supplementary Materials: The following are available online at http://www.mdpi.com/2077-0383/9/6/1834/s1, Table S1: Search strategy.

Author Contributions: Conceptualization, C.T., J.A.N., J.M., N.L., P.W.D., W.K., T.B., S.A.S., A.C., N.R.A., S.V., M.A.M. and W.C.; Data curation, C.T., N.L. and W.C.; Formal analysis, C.T. and W.C.; Funding acquisition, J.M.; Investigation, C.T., P.H., N.L., W.K. and W.C.; Methodology, C.T., J.A.N., P.H., W.K. and W.C.; Project administration, C.T. and T.B.; Resources, T.B.; Software, T.B.; Supervision, J.A.N., J.M., P.W.D., S.A.S., A.C., S.V., M.A.M. and W.C.; Validation, C.T., P.W.D., W.K., N.R.A. and W.C.; Visualization, J.A.N., P.H., J.M. and N.L.; Writing — original draft, C.T. and W.C.; Writing—review and editing, J.A.N., P.H., J.M., N.L., P.W.D., W.K., T.B., S.A.S., A.C., N.R.A., S.V., M.A.M. and W.C. All authors have read and agreed to the published version of the manuscript.

Funding: This research received no external funding.

Acknowledgments: None. All authors had access to the data and played essential roles in writing of the manuscript. Neyra is currently supported by an Early Career Pilot Grant from the National Center for Advancing Translational Sciences (NCATS), National Institutes of Health (NIH), through Grant UL1 TR001998.

Conflicts of Interest: The authors deny any conflict of interest.

\section{References}

1. Hu, M.C.; Shi, M.; Zhang, J.; Pastor, J.; Nakatani, T.; Lanske, B.; Razzaque, M.S.; Rosenblatt, K.P.; Baum, M.G.; Kuro-o, M.; et al. Klotho: A novel phosphaturic substance acting as an autocrine enzyme in the renal proximal tubule. FASEB J. 2010, 24, 3438-3450. [CrossRef]

2. Kuro-o, M. Klotho and aging. Biochim. Biophys. Acta 2009, 1790, 1049-1058. [CrossRef]

3. Bian, A.; Neyra, J.A.; Zhan, M.; Hu, M.C. Klotho, stem cells, and aging. Clin. Interv. Aging 2015, 10, 1233-1243. [PubMed]

4. Hu, M.C.; Shi, M.; Cho, H.J.; Adams-Huet, B.; Paek, J.; Hill, K.; Shelton, J.; Amaral, A.P.; Faul, C.; Taniguchi, M.; et al. Klotho and phosphate are modulators of pathologic uremic cardiac remodeling. J. Am. Soc. Nephrol. 2015, 26, 1290-1302. [CrossRef] [PubMed] 
5. Henao Agudelo, J.S.; Baia, L.C.; Ormanji, M.S.; Santos, A.R.P.; Machado, J.R.; Saraiva Câmara, N.O.; Navis, G.J.; de Borst, M.H.; Heilberg, I.P. Fish Oil Supplementation Reduces Inflammation but Does Not Restore Renal Function and Klotho Expression in an Adenine-Induced CKD Model. Nutrients 2018, 10, 1283. [CrossRef]

6. Huang, X.; Liu, T.; Zhao, M.; Fu, H.; Wang, J.; Xu, Q. Protective Effects of Moderate Ca Supplementation against Cd-Induced Bone Damage under Different Population-Relevant Doses in Young Female Rats. Nutrients 2019, 11, 849. [CrossRef] [PubMed]

7. Muñoz-Castañeda, J.R.; Rodelo-Haad, C.; Pendon-Ruiz de Mier, M.V.; Martin-Malo, A.; Santamaria, R.; Rodriguez, M. Klotho/FGF23 and Wnt Signaling as Important Players in the Comorbidities Associated with Chronic Kidney Disease. Toxins (Basel) 2020, 12, 185.

8. Buendía, P.; Carracedo, J.; Soriano, S.; Madueño, J.A.; Ortiz, A.; Martín-Malo, A.; Aljama, P.; Ramírez, R. Klotho Prevents NFkB Translocation and Protects Endothelial Cell From Senescence Induced by Uremia. J. Gerontol. A Biol. Sci. Med. Sci. 2015, 70, 1198-1209. [CrossRef] [PubMed]

9. Carracedo, J.; Buendía, P.; Merino, A.; Madueño, J.A.; Peralbo, E.; Ortiz, A.; Martín-Malo, A.; Aljama, P.; Rodríguez, M.; Ramírez, R. Klotho modulates the stress response in human senescent endothelial cells. Mech. Ageing Dev. 2012, 133, 647-654. [CrossRef] [PubMed]

10. Donate-Correa, J.; Martín-Núñez, E.; Ferri, C.; Hernández-Carballo, C.; Tagua, V.G.; Delgado-Molinos, A.; López-Castillo, Á.; Rodríguez-Ramos, S.; Cerro-López, P.; López-Tarruella, V.C.; et al. FGF23 and Klotho Levels are Independently Associated with Diabetic Foot Syndrome in Type 2 Diabetes Mellitus. J. Clin. Med. 2019, 8. [CrossRef] [PubMed]

11. Shimada, T.; Hasegawa, H.; Yamazaki, Y.; Muto, T.; Hino, R.; Takeuchi, Y.; Fujita, T.; Nakahara, K.; Fukumoto, S.; Yamashita, T. FGF-23 is a potent regulator of vitamin D metabolism and phosphate homeostasis. J. Bone Miner. Res. 2004, 19, 429-435. [CrossRef] [PubMed]

12. Komaba, H.; Fukagawa, M. FGF23-parathyroid interaction: Implications in chronic kidney disease. Kidney Int. 2010, 77, 292-298. [CrossRef] [PubMed]

13. Rodelo-Haad, C.; Santamaria, R.; Muñoz-Castañeda, J.R.; Pendón-Ruiz de Mier, M.V.; Martin-Malo, A.; Rodriguez, M. FGF23, Biomarker or Target? Toxins (Basel) 2019, 11, 175. [CrossRef] [PubMed]

14. Liu, Y.C.; Tsai, J.P.; Wang, L.H.; Lee, M.C.; Hsu, B.G. Positive correlation of serum fibroblast growth factor 23 with peripheral arterial stiffness in kidney transplantation patients. Clin. Chim. Acta 2020, 505, 9-14. [CrossRef]

15. Razzaque, M.S. The FGF23-Klotho axis: Endocrine regulation of phosphate homeostasis. Nat. Rev. Endocrinol. 2009, 5, 611-619. [CrossRef]

16. Shimada, T.; Kakitani, M.; Yamazaki, Y.; Hasegawa, H.; Takeuchi, Y.; Fujita, T.; Fukumoto, S.; Tomizuka, K.; Yamashita, T. Targeted ablation of Fgf23 demonstrates an essential physiological role of FGF23 in phosphate and vitamin D metabolism. J. Clin. Investig. 2004, 113, 561-568. [CrossRef]

17. Zou, D.; Wu, W.; He, Y.; Ma, S.; Gao, J. The role of klotho in chronic kidney disease. BMC Nephrol. 2018, 19, 285. [CrossRef] [PubMed]

18. Erben, R.G.; Andrukhova, O. FGF23-Klotho signaling axis in the kidney. Bone 2017, 100, $62-68$. [CrossRef] [PubMed]

19. Olauson, H.; Lindberg, K.; Amin, R.; Jia, T.; Wernerson, A.; Andersson, G.; Larsson, T.E. Targeted deletion of Klotho in kidney distal tubule disrupts mineral metabolism. J. Am. Soc. Nephrol. 2012, 23, 1641-1651. [CrossRef] [PubMed]

20. Martin, A.; David, V.; Quarles, L.D. Regulation and function of the FGF23/klotho endocrine pathways. Physiol. Rev. 2012, 92, 131-155. [CrossRef] [PubMed]

21. Hu, M.C.; Kuro-o, M.; Moe, O.W. Secreted klotho and chronic kidney disease. Adv. Exp. Med. Biol. 2012, 728, 126-157. [PubMed]

22. Takeshita, A.; Kawakami, K.; Furushima, K.; Miyajima, M.; Sakaguchi, K. Central role of the proximal tubular $\alpha$ Klotho/FGF receptor complex in FGF23-regulated phosphate and vitamin D metabolism. Sci. Rep. 2018, 8, 6917. [CrossRef] [PubMed]

23. Mencke, R.; Olauson, H.; Hillebrands, J.L. Effects of Klotho on fibrosis and cancer: A renal focus on mechanisms and therapeutic strategies. Adv. Drug Deliv. Rev. 2017, 121, 85-100. [PubMed]

24. Kuro-o, M.; Matsumura, Y.; Aizawa, H.; Kawaguchi, H.; Suga, T.; Utsugi, T.; Ohyama, Y.; Kurabayashi, M.; Kaname, T.; Kume, E.; et al. Mutation of the mouse klotho gene leads to a syndrome resembling ageing. Nature 1997, 390, 45-51. [PubMed] 
25. Maekawa, Y.; Ishikawa, K.; Yasuda, O.; Oguro, R.; Hanasaki, H.; Kida, I.; Takemura, Y.; Ohishi, M.; Katsuya, T.; Rakugi, H. Klotho suppresses TNF-alpha-induced expression of adhesion molecules in the endothelium and attenuates NF-kappaB activation. Endocrine 2009, 35, 341-346.

26. Nabeshima, Y. Toward a better understanding of Klotho. Sci. Aging Knowl. Environ. 2006, 2006 , pe11.

27. Jin, M.; Lv, P.; Chen, G.; Wang, P.; Zuo, Z.; Ren, L.; Bi, J.; Yang, C.W.; Mei, X.; Han, D. Klotho ameliorates cyclosporine A-induced nephropathy via PDLIM2/NF-kB p65 signaling pathway. Biochem. Biophys. Res. Commun. 2017, 486, 451-457. [PubMed]

28. Wang, Y.; Kuro-o, M.; Sun, Z. Klotho gene delivery suppresses Nox2 expression and attenuates oxidative stress in rat aortic smooth muscle cells via the cAMP-PKA pathway. Aging Cell 2012, 11, 410-417. [CrossRef] [PubMed]

29. Panesso, M.C.; Shi, M.; Cho, H.J.; Paek, J.; Ye, J.; Moe, O.W.; Hu, M.C. Klotho has dual protective effects on cisplatin-induced acute kidney injury. Kidney Int. 2014, 85, 855-870.

30. Hu, M.C.; Shi, M.; Zhang, J.; Quinones, H.; Griffith, C.; Kuro-o, M.; Moe, O.W. Klotho deficiency causes vascular calcification in chronic kidney disease. J. Am. Soc. Nephrol. 2011, 22, 124-136.

31. Kuro-o, M. Klotho as a regulator of oxidative stress and senescence. Biol. Chem. 2008, 389, 233-241. [CrossRef]

32. Liu, F.; Wu, S.; Ren, H.; Gu, J. Klotho suppresses RIG-I-mediated senescence-associated inflammation. Nat. Cell Biol. 2011, 13, 254-262. [CrossRef] [PubMed]

33. Doi, S.; Zou, Y.; Togao, O.; Pastor, J.V.; John, G.B.; Wang, L.; Shiizaki, K.; Gotschall, R.; Schiavi, S.; Yorioka, N.; et al. Klotho inhibits transforming growth factor-beta1 (TGF-beta1) signaling and suppresses renal fibrosis and cancer metastasis in mice. J. Biol. Chem. 2011, 286, 8655-8665. [PubMed]

34. Zhou, L.; Li, Y.; Zhou, D.; Tan, R.J.; Liu, Y. Loss of Klotho contributes to kidney injury by derepression of Wnt/beta-catenin signaling. J. Am. Soc. Nephrol. 2013, 24, 771-785. [CrossRef]

35. Sugiura, H.; Yoshida, T.; Shiohira, S.; Kohei, J.; Mitobe, M.; Kurosu, H.; Kuro-o, M.; Nitta, K.; Tsuchiya, K. Reduced Klotho expression level in kidney aggravates renal interstitial fibrosis. Am. J. Physiol. Renal Physiol. 2012, 302, F1252-F1264. [CrossRef]

36. Guan, X.; Nie, L.; He, T.; Yang, K.; Xiao, T.; Wang, S.; Huang, Y.; Zhang, J.; Wang, J.; Sharma, K.; et al. Klotho suppresses renal tubulo-interstitial fibrosis by controlling basic fibroblast growth factor-2 signalling. J. Pathol. 2014, 234, 560-572. [PubMed]

37. Huang, J.S.; Chuang, C.T.; Liu, M.H.; Lin, S.H.; Guh, J.Y.; Chuang, L.Y. Klotho attenuates high glucose-induced fibronectin and cell hypertrophy via the ERK1/2-p38 kinase signaling pathway in renal interstitial fibroblasts. Mol. Cell Endocrinol. 2014, 390, 45-53.

38. Shi, M.; Flores, B.; Gillings, N.; Bian, A.; Cho, H.J.; Yan, S.; Liu, Y.; Levine, B.; Moe, O.W.; Hu, M.C. AlphaKlotho Mitigates Progression of AKI to CKD through Activation of Autophagy. J. Am. Soc. Nephrol. 2016, 27, 2331-2345. [CrossRef]

39. Wang, Y.; Sun, Z. Current understanding of klotho. Ageing Res. Rev. 2009, 8, 43-51. [CrossRef]

40. Olauson, H.; Mencke, R.; Hillebrands, J.L.; Larsson, T.E. Tissue expression and source of circulating $\alpha$ Klotho. Bone 2017, 100, 19-35. [CrossRef]

41. Hu, M.C.; Kuro-o, M.; Moe, O.W. The emerging role of Klotho in clinical nephrology. Nephrol. Dial. Transplant. 2012, 27, 2650-2657. [CrossRef] [PubMed]

42. Amiri, F.S.; Khatami, M.R. Fibroblast Growth Factor 23 in Postrenal Transplant: An Often Forgotten Hormone. Exp. Clin. Transplant. 2016, 14, 606-616. [PubMed]

43. Neyra, J.A.; Li, X.; Mescia, F.; Ortiz-Soriano, V.; Adams-Huet, B.; Pastor, J.; Hu, M.C.; Toto, R.D.; Moe, O.W. Urine Klotho Is Lower in Critically Ill Patients With Versus Without Acute Kidney Injury and Associates With Major Adverse Kidney Events. Crit. Care Explor. 2019, 1, e0016. [CrossRef]

44. Sanchez-Niño, M.D.; Fernandez-Fernandez, B.; Ortiz, A. Klotho, the elusive kidney-derived anti-ageing factor. Clin. Kidney J. 2019, 13, 125-127.

45. Christov, M.; Neyra, J.A.; Gupta, S.; Leaf, D.E. Fibroblast Growth Factor 23 and Klotho in AKI. Semin. Nephrol. 2019, 39, 57-75. [CrossRef] [PubMed]

46. Neyra, J.A.; Hu, M.C. $\alpha$ Klotho and Chronic Kidney Disease. Vitam. Horm. 2016, 101, 257-310. [PubMed]

47. Hu, M.C.; Kuro-o, M.; Moe, O.W. Klotho and chronic kidney disease. Contrib. Nephrol. 2013, 180, 47-63. [PubMed]

48. Barker, S.L.; Pastor, J.; Carranza, D.; Quiñones, H.; Griffith, C.; Goetz, R.; Mohammadi, M.; Ye, J.; Zhang, J.; $\mathrm{Hu}$, M.C.; et al. The demonstration of $\alpha$ Klotho deficiency in human chronic kidney disease with a novel synthetic antibody. Nephrol. Dial. Transplant. 2015, 30, 223-233. [CrossRef] 
49. Seiler, S.; Rogacev, K.S.; Roth, H.J.; Shafein, P.; Emrich, I.; Neuhaus, S.; Floege, J.; Fliser, D.; Heine, G.H. Associations of FGF-23 and sKlotho with cardiovascular outcomes among patients with CKD stages 2-4. Clin. J. Am. Soc. Nephrol. 2014, 9, 1049-1058. [CrossRef]

50. Wang, Q.; Su, W.; Shen, Z.; Wang, R. Correlation between Soluble $\alpha$-Klotho and Renal Function in Patients with Chronic Kidney Disease: A Review and Meta-Analysis. Biomed. Res. Int. 2018, 2018, 9481475. [CrossRef]

51. Sari, F.; Inci, A.; Dolu, S.; Ellidag, H.Y.; Cetinkaya, R.; Ersoy, F.F. High serum soluble $\alpha$-Klotho levels in patients with autosomal dominant polycystic kidney disease. J. Investig. Med. 2017, 65, 358-362. [CrossRef]

52. Memmos, E.; Sarafidis, P.; Pateinakis, P.; Tsiantoulas, A.; Faitatzidou, D.; Giamalis, P.; Vasilikos, V.; Papagianni, A. Soluble Klotho is associated with mortality and cardiovascular events in hemodialysis. BMC Nephrol. 2019, 20, 217. [CrossRef] [PubMed]

53. Thongprayoon, C.; Hansrivijit, P.; Leeaphorn, N.; Acharya, P.; Torres-Ortiz, A.; Kaewput, W.; Kovvuru, K.; Kanduri, S.R.; Bathini, T.; Cheungpasitporn, W. Recent Advances and Clinical Outcomes of Kidney Transplantation. J. Clin. Med. 2020, 9, 1193. [CrossRef]

54. Thongprayoon, C.; Kaewput, W.; Kovvuru, K.; Hansrivijit, P.; Kanduri, S.R.; Bathini, T.; Chewcharat, A.; Leeaphorn, N.; Gonzalez-Suarez, M.L.; Cheungpasitporn, W. Promises of Big Data and Artificial Intelligence in Nephrology and Transplantation. J. Clin. Med. 2020, 9, 1107. [CrossRef]

55. Cheungpasitporn, W.; Thongprayoon, C.; Vaitla, P.K.; Chewcharat, A.; Hansrivijit, P.; Koller, F.L.; Mao, M.A.; Bathini, T.; Salim, S.A.; Katari, S.; et al. Degree of Glomerulosclerosis in Procurement Kidney Biopsies from Marginal Donor Kidneys and Their Implications in Predicting Graft Outcomes. J. Clin. Med. 2020, 9, 1469. [CrossRef]

56. Leeaphorn, N.; Thongprayoon, C.; Chon, W.J.; Cummings, L.S.; Mao, M.A.; Cheungpasitporn, W. Outcomes of kidney retransplantation after graft loss as a result of BK virus nephropathy in the era of newer immunosuppressant agents. Am. J. Transplant. 2020, 20, 1334-1340. [CrossRef] [PubMed]

57. Davis, C.L.; Delmonico, F.L. Living-donor kidney transplantation: a review of the current practices for the live donor. J. Am. Soc. Nephrol. 2005, 16, 2098-2110. [CrossRef] [PubMed]

58. Mizusaki, K.; Hasuike, Y.; Kimura, T.; Nagasawa, Y.; Kuragano, T.; Yamada, Y.; Nojima, M.; Yamamoto, S.; Nakanishi, T.; Ishihara, M. Inhibition of the Mammalian Target of Rapamycin May Augment the Increase in Soluble Klotho Levels in Renal Transplantation Recipients. Blood Purif. 2019, 47 (Suppl. 2), 12-18. [CrossRef] [PubMed]

59. Deng, G.; Yang, A.; Wu, J.; Zhou, J.; Meng, S.; Zhu, C.; Wang, J.; Shen, S.; Ma, J.; Liu, D. The Value of Older Donors' Klotho Level in Predicting Recipients' Short-Term Renal Function. Med. Sci. Monit. 2018, 24, 7936-7943. [CrossRef] [PubMed]

60. Kim, S.M.; Kim, S.J.; Ahn, S.; Min, S.-I.; Min, S.-K.; Ha, J. The Potential Role of Klotho as a Prognostic Biomarker in Deceased Donor Kidney Transplantation. Transplantation 2018, 102, S539. [CrossRef]

61. Kubota, M.; Hamasaki, Y.; Masuda, T.; Hashimoto, J.; Takahashi, Y.; Saito, A.; Yuasa, R.; Muramatsu, M.; Sakai, K.; Shishido, S. Fgf 23-Aklotho axis and phosphate metabolism in the early post-kidney transplantation period. In Pediatric Transplantation; Wiley: Hoboken, NJ, USA, 2019.

62. Tan, S.J.; Crosthwaite, A.; Langsford, D.; Obeysekere, V.; Ierino, F.L.; Roberts, M.A.; Hughes, P.D.; Hewitson, T.D.; Dwyer, K.M.; Toussaint, N.D. Mineral adaptations following kidney transplantation. Transpl. Int. 2017, 30, 463-473. [CrossRef] [PubMed]

63. Baloglu, İ; Turkmen, K.; Selçuk, N.Y.; Tonbul, H.Z.; Erdur, F.M. Fgf-23 and Klotho Levels in Renal Transplant Patients and Comparison with Hemodialysis Patients. In Nephrology Dialysis Transplantation; Oxford University Press: Oxford, UK, 2017.

64. Tartaglione, L.; Pasquali, M.; Rotondi, S.; Muci, M.L.; Leonangeli, C.; Farcomeni, A.; Fassino, V.; Mazzaferro, S. Interactions of sclerostin with FGF23, soluble klotho and vitamin D in renal transplantation. PLoS ONE 2017, 12, e0178637. [CrossRef] [PubMed]

65. Zaare Nahandi, M.; Ardalan, M.R.; Banagozar Mohamadi, A.; Ghorbani Haghjo, A.; Jabbarpor Bonyadi, M.; Mohamadian, T. Relationship of Serum Klotho Level With ACE Gene Polymorphism in Stable Kidney Allograft Recipients. Iran. J. Kidney Dis. 2017, 11, 151-156. [PubMed]

66. Bleskestad, I.H.; Thorsen, I.S.; Jonsson, G.; Skadberg, Ø.; Bergrem, H.; Gøransson, L.G. Soluble Klotho and intact fibroblast growth factor 23 in long-term kidney transplant patients. Eur. J. Endocrinol. 2015, 172, 343-350. [CrossRef] 
67. Malyszko, J.; Koc-Zorawska, E.; Matuszkiewicz-Rowinska, J. FGF23 and Klotho in relation to markers of endothelial dysfunction in kidney transplant recipients. Transplant. Proc. 2014, 46, 2647-2650. [CrossRef]

68. Akimoto, T.; Kimura, T.; Watanabe, Y.; Ishikawa, N.; Iwazu, Y.; Saito, O.; Muto, S.; Yagisawa, T.; Kusano, E. The impact of nephrectomy and renal transplantation on serum levels of soluble Klotho protein. Transplant. Proc. 2013, 45, 134-136. [CrossRef]

69. Kimura, T.; Akimoto, T.; Watanabe, Y.; Kurosawa, A.; Nanmoku, K.; Muto, S.; Kusano, E.; Yagisawa, T.; Nagata, D. Impact of Renal Transplantation and Nephrectomy on Urinary Soluble Klotho Protein. Transplant. Proc. 2015, 47, 1697-1699. [CrossRef]

70. Ponte, B.; Trombetti, A.; Hadaya, K.; Ernandez, T.; Fumeaux, D.; Iselin, C.; Martin, P.Y.; de Seigneux, S. Acute and long term mineral metabolism adaptation in living kidney donors: A prospective study. Bone 2014, 62, 36-42. [CrossRef]

71. Tan, S.J.; Hewitson, T.D.; Hughes, P.D.; Holt, S.G.; Toussaint, N.D. Changes in Markers of Mineral Metabolism After Living Kidney Donation. Transplant. Direct 2017, 3, e150. [CrossRef]

72. Thorsen, I.S.; Bleskestad, I.H.; Jonsson, G.; Skadberg, Ø.; Gøransson, L.G. Neutrophil Gelatinase-Associated Lipocalin, Fibroblast Growth Factor 23, and Soluble Klotho in Long-Term Kidney Donors. Nephron Extra 2016, 6, 31-39. [CrossRef]

73. Hong, Y.A.; Choi, D.E.; Lim, S.W.; Yang, C.W.; Chang, Y.K. Decreased parathyroid Klotho expression is associated with persistent hyperparathyroidism after kidney transplantation. Transplant. Proc. 2013, 45, 2957-2962. [CrossRef]

74. Ozdem, S.; Y1lmaz, V.T.; Ozdem, S.S.; Donmez, L.; Cetinkaya, R.; Suleymanlar, G.; Ersoy, F.F. Is Klotho F352V Polymorphism the Missing Piece of the Bone Loss Puzzle in Renal Transplant Recipients? Pharmacology 2015, 95, 271-278. [CrossRef]

75. Krajisnik, T.; Olauson, H.; Mirza, M.A.; Hellman, P.; Akerström, G.; Westin, G.; Larsson, T.E.; Björklund, P. Parathyroid Klotho and FGF-receptor 1 expression decline with renal function in hyperparathyroid patients with chronic kidney disease and kidney transplant recipients. Kidney Int. 2010, 78, 1024-1032. [CrossRef] [PubMed]

76. Moher, D.; Liberati, A.; Tetzlaff, J.; Altman, D.G. Preferred reporting items for systematic reviews and meta-analyses: The PRISMA statement. PLoS Med. 2009, 6, e1000097. [CrossRef]

77. DerSimonian, R.; Laird, N. Meta-analysis in clinical trials. Control. Clin. Trials 1986, 7, 177-188. [CrossRef]

78. Follmann, D.; Elliott, P.; Suh, I.; Cutler, J. Variance imputation for overviews of clinical trials with continuous response. J. Clin. Epidemiol. 1992, 45, 769-773. [CrossRef]

79. Cohen, J. Statistical power analysis. Curr. Dir. Psychol. Sci. 1992, 1, 98-101. [CrossRef]

80. Higgins, J.P.; Thompson, S.G.; Deeks, J.J.; Altman, D.G. Measuring inconsistency in meta-analyses. BMJ 2003, 327, 557-560. [CrossRef] [PubMed]

81. Easterbrook, P.J.; Berlin, J.A.; Gopalan, R.; Matthews, D.R. Publication bias in clinical research. Lancet 1991, 337, 867-872. [CrossRef]

82. Egger, M.; Davey Smith, G.; Schneider, M.; Minder, C. Bias in meta-analysis detected by a simple, graphical test. BMJ 1997, 315, 629-634. [CrossRef]

83. John, G.B.; Cheng, C.Y.; Kuro-o, M. Role of Klotho in aging, phosphate metabolism, and CKD. Am. J. Kidney Dis. 2011, 58, 127-134. [CrossRef] [PubMed]

84. Kalaitzidis, R.G.; Duni, A.; Siamopoulos, K.C. Klotho, the Holy Grail of the kidney: from salt sensitivity to chronic kidney disease. Int. Urol. Nephrol. 2016, 48, 1657-1666. [CrossRef] [PubMed]

85. Van Londen, M.; Aarts, B.M.; Deetman, P.E.; van der Weijden, J.; Eisenga, M.F.; Navis, G.; Bakker, S.J.L.; de Borst, M.H. Post-Transplant Hypophosphatemia and the Risk of Death-Censored Graft Failure and Mortality after Kidney Transplantation. Clin. J. Am. Soc. Nephrol. 2017, 12, 1301-1310. [CrossRef] [PubMed]

86. Nakai, K.; Mitsuiki, K.; Kuroki, Y.; Nishiki, T.; Motoyama, K.; Nakano, T.; Kitazono, T. Relative hypophosphatemia early after transplantation is a predictor of good kidney graft function. Clin. Exp. Nephrol. 2019, 23, 1161-1168. [CrossRef]

87. Hu, M.C.; Moe, O.W. Klotho as a potential biomarker and therapy for acute kidney injury. Nat. Rev. Nephrol. 2012, 8, 423-429. [CrossRef] [PubMed]

88. Aiello, S.; Noris, M. Klotho in acute kidney injury: Biomarker, therapy, or a bit of both? Kidney Int. 2010, 78, 1208-1210. [CrossRef] [PubMed] 
89. Li, P.; Shi, M.; Maique, J.; Shaffer, J.; Yan, S.; Moe, O.W.; Hu, M.C. Beclin 1/Bcl-2 complex-dependent autophagy activity modulates renal susceptibility to ischemia-reperfusion injury and mediates renoprotection by Klotho. American journal of physiology. Am. J. Physiol. Renal Physiol. 2020, 318, F772-F792. [CrossRef] [PubMed]

90. Castellano, G.; Intini, A.; Stasi, A.; Divella, C.; Gigante, M.; Pontrelli, P.; Franzin, R.; Accetturo, M.; Zito, A.; Fiorentino, M.; et al. Complement Modulation of Anti-Aging Factor Klotho in Ischemia/Reperfusion Injury and Delayed Graft Function. Am. J. Transplant. 2016, 16, 325-333. [CrossRef]

91. De Sandes-Freitas, T.V.; Felipe, C.R.; Aguiar, W.F.; Cristelli, M.P.; Tedesco-Silva, H.; Medina-Pestana, J.O. Prolonged Delayed Graft Function Is Associated with Inferior Patient and Kidney Allograft Survivals. PLOS ONE 2015, 10, e0144188. [CrossRef] [PubMed]

92. Weber, S.; Dienemann, T.; Jacobi, J.; Eckardt, K.U.; Weidemann, A. Delayed graft function is associated with an increased rate of renal allograft rejection: A retrospective single center analysis. PLoS ONE 2018, 13, e0199445. [CrossRef] [PubMed]

93. Lee, C.H.; Kim, G.H. Electrolyte and Acid-base disturbances induced by clacineurin inhibitors. Electrolyte Blood Press 2007, 5, 126-130. [PubMed]

94. Demeule, M.; Béliveau, R. Cyclosporin inhibits phosphate transport and stimulates alkaline phosphatase activity in renal BBMV. Am. J. Physiol. 1991, 260, F518-F524. [PubMed]

95. Falkiewicz, K.; Nahaczewska, W.; Boratynska, M.; Owczarek, H.; Klinger, M.; Kaminska, D.; Wozniak, M.; Szepietowski, T.; Patrzalek, D. Tacrolimus decreases tubular phosphate wasting in renal allograft recipients. Transplant. Proc. 2003, 35, 2213-2215.

96. Messa, P.; Cafforio, C.; Alfieri, C. Calcium and phosphate changes after renal transplantation. J. Nephrol. 2010, 23 (Suppl. 16), S175-S181. [PubMed]

97. Sakhaee, K. Post-renal transplantation hypophosphatemia. Pediatr. Nephrol. 2010, 25, 213-220.

98. Cheungpasitporn, W.; Thongprayoon, C.; Hansrivijit, P.; Medaura, J.; Chewcharat, A.; Bathini, T.; Mao, M.; Erickson, S. Impact of admission calcium-phosphate product on 1-year mortality among hospitalized patients. Adv. Biomed. Res. 2020, 9, 14.

99. Thongprayoon, C.; Cheungpasitporn, W.; Mao, M.A.; Erickson, S.B. Calcium-phosphate product and its impact on mortality in hospitalized patients. Nephrology (Carlton) 2020, 25, 22-28. [PubMed]

100. Pichler, G.; Haller, M.C.; Kainz, A.; Wolf, M.; Redon, J.; Oberbauer, R. Prognostic value of bone- and vascular-derived molecular biomarkers in hemodialysis and renal transplant patients: A systematic review and meta-analysis. Nephrol. Dial. Transplant. 2017, 32, 1566-1578.

101. Lentine, K.L.; Patel, A. Risks and outcomes of living donation. Adv. Chronic Kidney Dis. 2012, 19, $220-228$.

102. Ommen, E.S.; Winston, J.A.; Murphy, B. Medical risks in living kidney donors: absence of proof is not proof of absence. Clin. J. Am. Soc. Nephrol. 2006, 1, 885-895.

103. Asgari, E.; Hilton, R.M. One size does not fit all: Understanding individual living kidney donor risk. Pediatr. Nephrol. 2020. [CrossRef] [PubMed]

104. Fehrman-Ekholm, I.; Elinder, C.G.; Stenbeck, M.; Tydén, G.; Groth, C.G. Kidney donors live longer. Transplantation 1997, 64, 976-978. [CrossRef]

105. Okamoto, M.; Akioka, K.; Nobori, S.; Ushigome, H.; Kozaki, K.; Kaihara, S.; Yoshimura, N. Short- and long-term donor outcomes after kidney donation: analysis of 601 cases over a 35-year period at Japanese single center. Transplantation 2009, 87, 419-423. [CrossRef] [PubMed]

106. Ibrahim, H.N.; Foley, R.; Tan, L.; Rogers, T.; Bailey, R.F.; Guo, H.; Gross, C.R.; Matas, A.J. Long-term consequences of kidney donation. N. Engl. J. Med. 2009, 360, 459-469. [CrossRef] [PubMed]

107. Segev, D.L.; Muzaale, A.D.; Caffo, B.S.; Mehta, S.H.; Singer, A.L.; Taranto, S.E.; McBride, M.A.; Montgomery, R.A. Perioperative mortality and long-term survival following live kidney donation. JAMA 2010, 303, 959-966. [CrossRef] [PubMed]

108. O’Keeffe, L.M.; Ramond, A.; Oliver-Williams, C.; Willeit, P.; Paige, E.; Trotter, P.; Evans, J.; Wadström, J.; Nicholson, M.; Collett, D.; et al. Mid- and Long-Term Health Risks in Living Kidney Donors: A Systematic Review and Meta-analysis. Ann. Intern. Med. 2018, 168, 276-284. [CrossRef] [PubMed]

109. Garg, A.X.; Meirambayeva, A.; Huang, A.; Kim, J.; Prasad, G.V.; Knoll, G.; Boudville, N.; Lok, C.; McFarlane, P.; Karpinski, M.; et al. Cardiovascular disease in kidney donors: Matched cohort study. BMJ 2012, 344, e1203. [CrossRef]

110. Musgrove, J.; Wolf, M. Regulation and Effects of FGF23 in Chronic Kidney Disease. Annu. Rev. Physiol. 2020, 82, 365-390. [CrossRef] 
111. Wolf, M. Forging forward with 10 burning questions on FGF23 in kidney disease. J. Am. Soc. Nephrol. 2010, 21, 1427-1435. [CrossRef]

112. Marthi, A.; Donovan, K.; Haynes, R.; Wheeler, D.C.; Baigent, C.; Rooney, C.M.; Landray, M.J.; Moe, S.M.; Yang, J.; Holland, L.; et al. Fibroblast Growth Factor-23 and Risks of Cardiovascular and Noncardiovascular Diseases: A Meta-Analysis. J. Am. Soc. Nephrol. 2018, 29, 2015-2027. [CrossRef]

113. Grabner, A.; Amaral, A.P.; Schramm, K.; Singh, S.; Sloan, A.; Yanucil, C.; Li, J.; Shehadeh, L.A.; Hare, J.M.; David, V.; et al. Activation of Cardiac Fibroblast Growth Factor Receptor 4 Causes Left Ventricular Hypertrophy. Cell Metab. 2015, 22, 1020-1032. [CrossRef] [PubMed]

114. Moody, W.E.; Ferro, C.J.; Edwards, N.C.; Chue, C.D.; Lin, E.L.; Taylor, R.J.; Cockwell, P.; Steeds, R.P.; Townend, J.N. Cardiovascular Effects of Unilateral Nephrectomy in Living Kidney Donors. Hypertension 2016, 67, 368-377. [CrossRef] [PubMed]

115. Vervloet, M.G.; Massy, Z.A.; Brandenburg, V.M.; Mazzaferro, S.; Cozzolino, M.; Ureña-Torres, P.; Bover, J.; Goldsmith, D. Bone: A new endocrine organ at the heart of chronic kidney disease and mineral and bone disorders. Lancet Diabetes Endocrinol. 2014, 2, 427-436. [CrossRef]

116. Hum, J.M.; O’Bryan, L.M.; Tatiparthi, A.K.; Cass, T.A.; Clinkenbeard, E.L.; Cramer, M.S.; Bhaskaran, M.; Johnson, R.L.; Wilson, J.M.; Smith, R.C.; et al. Chronic Hyperphosphatemia and Vascular Calcification Are Reduced by Stable Delivery of Soluble Klotho. J. Am. Soc. Nephrol. 2017, 28, 1162-1174. [CrossRef] [PubMed]

117. Xie, J.; Yoon, J.; An, S.W.; Kuro-o, M.; Huang, C.L. Soluble Klotho Protects against Uremic Cardiomyopathy Independently of Fibroblast Growth Factor 23 and Phosphate. J. Am. Soc. Nephrol. 2015, 26, 1150-1160. [CrossRef] [PubMed]

118. Xie, J.; Cha, S.K.; An, S.W.; Kuro, O.M.; Birnbaumer, L.; Huang, C.L. Cardioprotection by Klotho through downregulation of TRPC6 channels in the mouse heart. Nat. Commun. 2012, 3, 1238. [CrossRef] [PubMed]

119. Leone, F.; Lofaro, D.; Gigliotti, P.; Perri, A.; Vizza, D.; Toteda, G.; Lupinacci, S.; Armentano, F.; Papalia, T.; Bonofiglio, R. Soluble Klotho levels in adult renal transplant recipients are modulated by recombinant human erythropoietin. J. Nephrol. 2014, 27, 577-585. [CrossRef]

120. Donate-Correa, J.; Henríquez-Palop, F.; Martín-Núñez, E.; Pérez-Delgado, N.; Muros-de-Fuentes, M.; Mora-Fernández, C.; Navarro-González, J.F. Effect of Paricalcitol on FGF-23 and Klotho in Kidney Transplant Recipients. Transplantation 2016, 100, 2432-2438. [CrossRef]

121. Prather, A.A.; Epel, E.S.; Arenander, J.; Broestl, L.; Garay, B.I.; Wang, D.; Dubal, D.B. Longevity factor klotho and chronic psychological stress. Transl. Psychiatry 2015, 5, e585. [CrossRef]

122. Jurado-Fasoli, L.; Amaro-Gahete, F.J.; De-la, O.A.; Gutiérrez, Á.; Castillo, M.J. Alcohol consumption and S-Klotho plasma levels in sedentary healthy middle-aged adults: A cross sectional study. Drug Alcohol Depend. 2019, 194, 107-111. [CrossRef]

123. Amaro-Gahete, F.J.; De-la, O.A.; Jurado-Fasoli, L.; Ruiz, J.R.; Castillo, M.J.; Gutiérrez, Á. Role of Exercise on S-Klotho Protein Regulation: A Systematic Review. Curr. Aging Sci. 2018, 11, 100-107. [CrossRef] [PubMed]

124. Jurado-Fasoli, L.; Amaro-Gahete, F.J.; De-la, O.A.; Martinez-Tellez, B.; Ruiz, J.R.; Gutiérrez, Á.; Castillo, M.J. Adherence to the Mediterranean diet, dietary factors, and S-Klotho plasma levels in sedentary middle-aged adults. Exp. Gerontol. 2019, 119, 25-32. [CrossRef] [PubMed]

125. Deng, G.; Liu, D. Klotho: A Promising Biomarker Closely Related to Kidney Transplant. Exp. Clin. Transplant. 2018, 16, 253-258. [PubMed]

126. Neyra, J.A.; Moe, O.W.; Pastor, J.; Gianella, F.; Sidhu, S.S.; Sarnak, M.J.; Ix, J.H.; Drew, D.A. Performance of soluble Klotho assays in clinical samples of kidney disease. Clin. Kidney J. 2020, 13, 235-244. [CrossRef] [PubMed]

(C) 2020 by the authors. Licensee MDPI, Basel, Switzerland. This article is an open access article distributed under the terms and conditions of the Creative Commons Attribution (CC BY) license (http://creativecommons.org/licenses/by/4.0/). 